Article

\title{
Response of Compacted Bentonites to Thermal and Thermo-Hydraulic Loadings at High Temperatures
}

\author{
Snehasis Tripathy *, Hywel Rhys Thomas and Panagiotis Stratos \\ Geoenvironmental Research Centre, School of Engineering, Cardiff University, Queen's Buildings, West Groove, \\ Newport Road, Cardiff CF24 3AA, UK; ThomasHR@cardiff.ac.uk (H.R.T.); StratosP1@cardiff.ac.uk (P.S.) \\ * Correspondence: TripathyS@cardiff.ac.uk; Tel.: +44-29-2087-9377
}

Received: 9 April 2017; Accepted: 3 July 2017; Published: 7 July 2017

\begin{abstract}
The final disposal of high-level nuclear waste in many countries is preferred to be in deep geological repositories. Compacted bentonites are proposed for use as the buffer surrounding the waste canisters which may be subjected to both thermal and hydraulic loadings. A significant increase in the temperature is anticipated within the buffer, particularly during the early phase of the repository lifetime. In this study, several non-isothermal and non-isothermal hydraulic tests were carried on compacted MX80 bentonite. Compacted bentonite specimens (water content $=15.2 \%$, dry density $=1.65 \mathrm{Mg} / \mathrm{m}^{3}$ ) were subjected to a temperature of either 85 or $150{ }^{\circ} \mathrm{C}$ at one end, whereas the temperature at the opposite end was maintained at $25^{\circ} \mathrm{C}$. During the non-isothermal hydraulic tests, water was supplied from the opposite end of the heat source. The temperature and relative humidity were monitored along predetermined depths of the specimens. The profiles of water content, dry density, and degree of saturation were established after termination of the tests. The test results showed that thermal gradients caused redistribution of the water content, whereas thermo-hydraulic gradients caused both redistribution and an increase in the water content within compacted bentonites, both leading to development of axial stress of various magnitudes. The applied water injection pressures $(5$ and $600 \mathrm{kPa}$ ) and temperature gradients appeared to have very minimal impact on the magnitude of axial stress developed. The thickness of thermal insulation layer surrounding the testing devices was found to influence the temperature and relative humidity profiles thereby impacting the redistribution of water content within compacted bentonites. Under the influence of both the applied thermal and thermo-hydraulic gradients, the dry density of the bentonite specimens increased near the heat source, whereas it decreased at the opposite end. The test results emphasized the influence of elevated temperatures (up to $150{ }^{\circ} \mathrm{C}$ ) on the thermo-hydro-mechanical response of compacted bentonites in the nuclear waste repository settings.
\end{abstract}

Keywords: bentonite; radioactive waste disposal; temperature; hydration; thermal loading; hydraulic loading; clay response; unsaturated soil; stress; laboratory tests

\section{Introduction}

Compacted bentonites are proposed to be used as the barrier and backfilling materials in underground disposal of high-level nuclear waste in many countries. Due to the high swelling and low permeability characteristics, the bentonite buffer surrounding the waste canisters is expected to retard the flow of radionuclide to the natural barrier systems. The in situ boundary conditions dictate exposure of compacted unsaturated bentonites to elevated temperature from the waste canisters and hydration upon fluid uptake from the surrounding host rock. Bentonites exhibit swelling during the hydration process, whereas the drying process is accompanied by a decrease in the volume. Under confined condition and upon exposure to a hydration source, the development of swelling pressure is expected to provide stability to the waste disposal repositories [1-4]. 
Several studies have been carried out in the past that focused in investigating the coupled thermo-hydro-mechanical behaviour of compacted bentonites and bentonite-sand mixtures when subjected to thermal, hydraulic, and thermo-hydraulic gradients [5-18]. The reported laboratory tests have been conducted at various temperatures $\left(60\right.$ to $\left.140{ }^{\circ} \mathrm{C}\right)$ and water injection pressures ( $5 \mathrm{kPa}$ to $2 \mathrm{MPa}$ ). A choice of water injection pressure depends upon the pore water pressure conditions in the repository. The variations of the temperature and relative humidity within compacted bentonites were monitored in several investigations. Similarly, the changes in the dry density, the water content, the degree of saturation and the concentration of anions and cations were measured after the termination of the tests in various studies $[9,15,16]$. A variation of the axial stress during the tests was also monitored in some cases (see for example, $[17,18]$ ). This information is crucial in order to understand the coupled thermo-hydraulic-mechanical-chemical response of the engineered barriers, both under short and long-term in situ conditions involving anticipated temperatures and water pressures.

Studies concerning the thermal and thermo-hydraulic response of compacted bentonites at high temperatures are of significant interest, particularly for understanding the early-life phase of deep geological disposal facilities. Very high temperature of spent fuel, radioactive decay of wastes, and formation of high thermal zones at and near the interface of waste canisters and the buffer are some of the in situ conditions which demand detailed investigations concerning the response of compacted bentonites under non-isothermal and non-isothermal hydraulic boundary conditions involving high temperatures. A detailed review of the literature suggested that a majority of the laboratory tests in the past have been conducted by considering an applied temperature of less than $100{ }^{\circ} \mathrm{C}$ [5-18]. A thermal limit of about $100{ }^{\circ} \mathrm{C}$ or lower is preferable in order to eliminate the risks associated with chemical alteration of the buffer and backfilling materials and the subsequent changes in swelling and hydraulic properties [14,19-22]. Horseman and McEwen [23] stated that the magnitude of temperature in the waste repositories influences the decisions concerning the spacing between waste package, the distance between disposal galleries, and therefore the overall size of the repository. Sellin and Leupin [22] stated that the heat generation from the waste decreases relatively rapidly with time, and montmorillonite alteration is a slow process, any temperature criteria will always be somewhat arbitrary. Studies in the past have shown that the hydraulic properties of initially saturated bentonites did not deteriorate at temperatures up to $120^{\circ} \mathrm{C}$ and hence it may be anticipated that unsaturated bentonite would remain stable even at high very temperatures [20]. Zheng et al. [24] stated that an applied temperature of $200{ }^{\circ} \mathrm{C}$ may cause a decrease in the swelling pressure, a reduction in the smectite volume fraction, and an increase in the total stress due to thermal pressurization.

During the lifetime of the repositories the heat originated from the waste may dissipate due to various processes, such as radiation, conduction, and convection. The thermal properties of the host rock, the magnitudes of temperature and water pressure, and the thickness of compacted bentonite may influence the temperature rise within the buffer, which may in turn influence the distribution of water and development of stress within the engineered barrier systems. The main objective of this paper is to bring out the influence of thermal and thermo-hydraulic gradients involving high temperatures and high water injection pressure on the behaviour of compacted bentonites.

\section{Materials and Methods}

MX80 bentonite was procured from TOLSA UK Ltd (Scunthorpe, UK; www.tolsa.com) for this research work. The initial water content, specific gravity, liquid limit and plastic limit of the bentonite were found to be $15.2 \%, 2.8,400 \%$ and $58 \%$, respectively. The specific surface area for the bentonite was determined by the ethylene glycol mono-ethyl ether (EGME) method and was found to be $654 \mathrm{~m}^{2} / \mathrm{g}$. The ammonium acetate extraction method [25] was used to determine the type and amount of cations present in the bentonite. The bentonite was found to contain $\mathrm{Na}^{+}$ (67.12 meq/100 g), $\mathrm{K}^{+}(1.95 \mathrm{meq} / 100 \mathrm{~g}), \mathrm{Ca}^{2+}(44.67 \mathrm{meq} / 100 \mathrm{~g})$ and $\mathrm{Mg}^{2+}(14.35 \mathrm{meq} / 100 \mathrm{~g})$. The type and amount of soluble ions were determined by saturation extract method using water that enabled calculation of the fractional exchangeable cations as: $\mathrm{Na}^{+}(44.83 \mathrm{meq} / 100 \mathrm{~g}), \mathrm{K}^{+}(1.20 \mathrm{meq} / 100 \mathrm{~g}), \mathrm{Ca}^{2+}$ 
(42.11 meq/100 g), and $\mathrm{Mg}^{2+}(3.29 \mathrm{meq} / 100 \mathrm{~g})$. The total cation exchange capacity of the bentonite was found to be $91.43 \mathrm{meq} / 100 \mathrm{~g}$. The X-ray diffraction analysis was undertaken by using a Philips automated diffractometer (PANalytical, Cambridge, UK). The MX80 bentonite used in this study was found to contain $72 \%$ montmorillonite, $12 \%$ quartz and $16 \%$ other minerals (e.g., cristoballite, feldspars, etc.).

Two types of thermo-hydraulic column cells (TH column cells) were used in this study. The schematic diagrams of the devices are shown in Figure 1. For the tests at $85^{\circ} \mathrm{C}$, a TH column cell (Device A in Figure 1a) proposed by Tripathy et al. [18] was used, whereas several new TH column cells were fabricated and used for the tests at $150{ }^{\circ} \mathrm{C}$ (Device B in Figure 1b). The devices enabled applying both thermal and thermo-hydraulic gradients, and facilitated measuring the relative humidity and the temperature at predetermined locations along the depth of specimens and the axial stress at the top of the specimens.

$\begin{array}{ll}\text { 1. Device base } & \text { 13. Fluid reservoir } \\ \text { 2. PTFE disc } & \text { 14. Copper coil } \\ \text { 3. Heater } & \text { 15. Water inlet } \\ \begin{array}{ll}\text { 4. Heater cable } & \text { 16. Thermocouple } \\ \text { 5. Duplex thermocouple } & \text { 17. Pressure gauge with } \\ \text { 6. Specimen cell } & \text { quick air release and } \\ \text { 7. PTFE liner } & \text { safety valves } \\ \text { 8. Compacted specimen } & \text { 18. To load cell and } \\ \text { 9. Relative humidity and } & \text { horizontal restraint of } \\ \text { temperature probe } & \text { loading frame } \\ \begin{array}{l}\text { 10. Thermal insulation } \\ \text { 11. Piston with porous plate } \\ \text { 12. Connecting ring }\end{array} & \text { 19. Heavy bolts with } \\ \end{array}\end{array}$

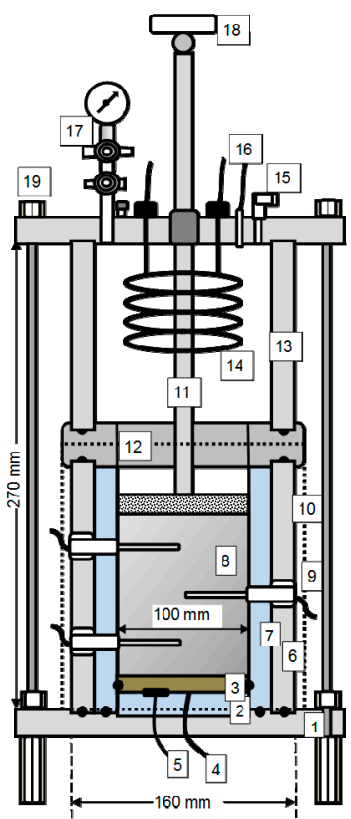

(a)

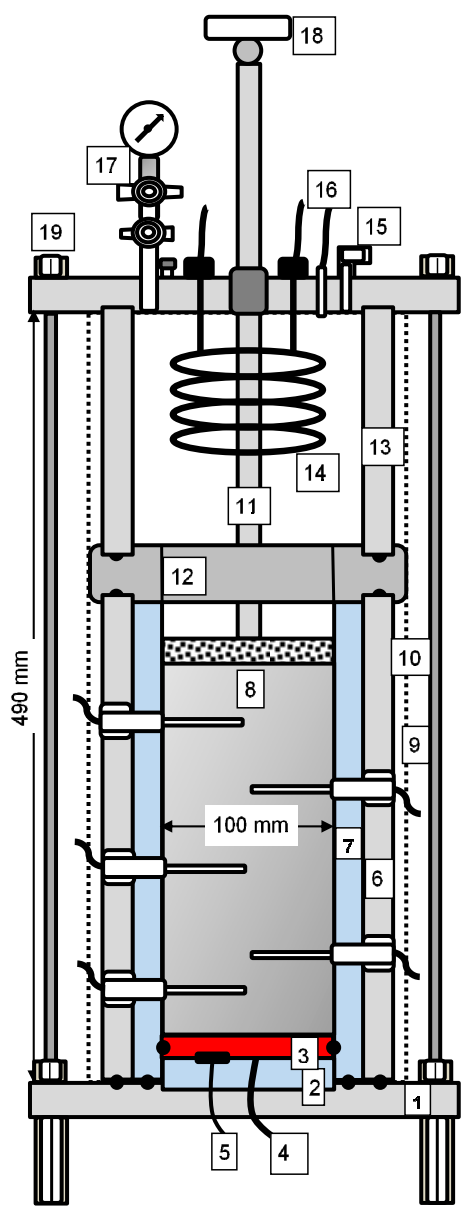

(b)

Figure 1. Schematics of the thermo-hydraulic column cells used in this study: (a) device A, for tests at $85^{\circ} \mathrm{C}$; (b) device $\mathrm{B}$, for tests at $150{ }^{\circ} \mathrm{C}$.

The main features of the TH column cells were similar except that the dimensions and the accessories used were different. The main components of the TH column cells are a stainless steel base, a central section $(100 \mathrm{~mm}$ diameter and $140 \mathrm{~mm}$ high for device A and $100 \mathrm{~mm}$ diameter and $360 \mathrm{~mm}$ 
high for device B), a connecting ring, and a top part that acts as a water reservoir for supplying water to the specimen during hydraulic tests. A polytetrafluoroethylene (PTFE) forms the liner of the central section for reducing the heat loss through the outer wall of the cells during tests. Metal heaters were used to apply thermal loading at the bottom end of the specimens. Dual thermocouples were attached at the centre of the heater. One of the thermocouple was connected to the heater controller and the other was connected to a data logger. During a test, the thermocouple that was connected to the heater controller maintained the predetermined temperature of the metal heater. The other thermocouple measured the actual temperature on the surface of the heater. The loading plunger in each cell was fitted with a metal porous disc which remained in contact with specimen during a test.

The diameter of commercially available relative humidity and temperature probes that are suitable for using at high temperature applications is usually larger than that of the probes which are used at lower temperatures. Therefore, in order to minimize the interference of electrical signal, it is preferable to maximize the distance between the probes, which in turn requires consideration of a thicker bentonite specimen. This was one of the main reasons behind development of the TH cell B. The relative humidity and temperature probes were procured from Vaisala (Helsinki, Finland). The accuracy of the probes (HMP110) used in case of device A was $\pm 2.5 \%$ and $\pm 3.5 \%$ for the range of relative humidity between 0 to $90 \%$ and 90 to $100 \%$, respectively. The accuracy of temperature sensor in this case was $\pm 0.4{ }^{\circ} \mathrm{C}$ for the range of temperature measurement between 40 and $80{ }^{\circ} \mathrm{C}$. The accuracy of the probes (HMT315) used in device B was $\pm(1.5+0.015 \times$ reading $) \%$ for the range of relative humidity between 0 to $100 \%$ and for an operating temperature range of -40 to $180{ }^{\circ} \mathrm{C}$. The accuracy of the temperature sensor in this case was $\pm 0.2^{\circ} \mathrm{C}$.

The central section of device A (Figure 1a) contains three holes at distances of 20,40, and $60 \mathrm{~mm}$ from the heater. The positions of the holes are staggered by an angle of $120^{\circ}$. The central section of device B (Figure 1b) contains five holes at distances of 40, 60, 120, 180, and $240 \mathrm{~mm}$ from the heater. The positions of the holes are staggered by an angle of $90^{\circ}$. For the non-isothermal tests in device $\mathrm{B}$, the hole at a distance of $40 \mathrm{~mm}$ from the heater was not used. Similarly, holes were drilled on compacted bentonite specimens, aligned with the holes in the central section of the cells for accommodating the relative humidity and temperature measurement probes.

In total, nine tests were carried. The duration of the tests was varied between about three to ten months. Four independent tests (two non-isothermal and two non-isothermal hydraulic tests) were carried out on compacted bentonite specimens using device A, whereas five tests (two non-isothermal and three non-isothermal hydraulic tests) were carried out using device B. Table 1 presents the details of the tests carried out in this investigation.

Table 1. Details of the non-isothermal and non-isothermal hydraulic tests carried out in this study.

\begin{tabular}{|c|c|c|c|c|c|}
\hline Test No. & $\begin{array}{l}\text { TH Cell Used }{ }^{1} \\
\text { (Figure 1) }\end{array}$ & $\begin{array}{c}\text { Temperature at } \\
\text { the Base }\left({ }^{\circ} \mathrm{C}\right)\end{array}$ & $\begin{array}{l}\text { Applied Water } \\
\text { Pressure (kPa) }\end{array}$ & $\begin{array}{l}\text { Thickness of Outer } \\
\text { Insulation (mm) }\end{array}$ & $\begin{array}{l}\text { Duration of } \\
\text { Tests (Days) }\end{array}$ \\
\hline $\mathrm{T} 1$ & $\mathrm{~A}$ & 85 & None & 20 & 110 \\
\hline $\mathrm{T} 2$ & A & 85 & None & 40 & 155 \\
\hline T3 & B & 150 & None & 20 & 138 \\
\hline $\mathrm{T} 4$ & B & 150 & None & 40 & 188 \\
\hline TH5 & $\mathrm{A}$ & 85 & 600 & 20 & 280 \\
\hline TH6 & A & 85 & 600 & 40 & 280 \\
\hline TH7 & B & 150 & 5 & 40 & 90 \\
\hline TH8 & B & 150 & 600 & 40 & 182 \\
\hline TH9 & B & 150 & 600 & 40 & 300 \\
\hline
\end{tabular}

TH: thermo-hydraulic. ${ }^{1}$ Height of specimen in TH cell A = $80 \mathrm{~mm}$; height of specimen in TH cell B = $300 \mathrm{~mm}$.

Cylindrical bentonite specimens were prepared by statically compacting bentonite powder (water content $=15.2 \%$ ) to a targeted dry density of $1.65 \pm 0.1 \mathrm{Mg} / \mathrm{m}^{3}$. A high capacity loading frame was used for the compaction process. The targeted dry density of the specimens was achieved following 
removal of the applied compaction stress which caused an axial expansion of the bentonite specimens. Compaction of bentonite powder was carried out inside the central section of the cells. Prior to preparing the specimens, the inner surfaces of the specimen cells were lubricated with silicon grease. For the tests in device A, compacted specimens (100 mm diameter, $80 \mathrm{~mm}$ high) were prepared in four layers, each $20 \mathrm{~mm}$ thick. To achieve the desired dry density, each layer was subjected to a static load of about $90 \mathrm{kN}$ (applied static compaction pressure $=11.46 \mathrm{MPa}$ ). For the tests in device B, specimens (100 mm diameter, $300 \mathrm{~mm}$ high) were prepared in ten layers, each $30 \mathrm{~mm}$ thick. In this case, each layer was subjected to a static load of about $120 \mathrm{kN}$ (applied static compaction pressure $=15.28 \mathrm{MPa}$ ).

Prior to the tests, the relative humidity and temperature measurement probes were inserted through the predrilled holes. Commercially available synthetic fluorinated oil based grease was applied at the junctions between different sections of the cell to prevent the vapour leakage. The TH column cells were covered with thermal insulations during the tests. For the non-isothermal tests using devices A and B (i.e., for Tests T1-T4) two types of thermal insulations were used, such as a $20 \mathrm{~mm}$ thick rock-wool covered with duct tape and a $40 \mathrm{~mm}$ thick rock-wool covered with reflective tape. All the non-isothermal hydraulic tests, except Test TH5 were conducted with the outer thermal insulation that was comprised of a $40 \mathrm{~mm}$ thick rock-wool covered with reflective tape. For Test TH5, a $20 \mathrm{~mm}$ thick insulation was used. During a test the load cell was positioned on top of the plunger and restrained against any movement by using a loading frame.

For the non-isothermal tests (for Tests T1 to T4), compacted bentonite specimens were either subjected to a temperature of $85^{\circ} \mathrm{C}$ (device A) or $150{ }^{\circ} \mathrm{C}$ (device B) (see Table 1) at the bottom end by raising the temperature of the heater, whereas at the top, a temperature of $25^{\circ} \mathrm{C}$ was maintained throughout the tests. For the non-isothermal hydraulic tests (Tests TH5 to TH9), in addition to the applied temperatures (Table 1), deionized water was supplied from the top end of the specimens. The applied water pressure was $600 \mathrm{kPa}$ for Tests TH5, TH6, TH8, and TH9, whereas the applied water pressure was $5.0 \mathrm{kPa}$ for Test TH7.

Temperature control at the top end of the specimens was achieved via circulation of water within a copper coil. A heating/refrigerating water circulator was used to control the temperature of the circulating water within the coil. The water circulator had a proportional integral-derivative (PID) controller and an adjustable over heating cut out. The empty space on top of the loading plunger was filled with deionized water for supplying water to the specimens during Tests TH5 to TH9. During Tests $\mathrm{T} 1$ to $\mathrm{T} 4$, the temperature of the water within the coil was maintained at $25^{\circ} \mathrm{C}$. The relative humidity, temperature, and axial stress were monitored during all tests. After termination of the tests, the specimens were extruded from the devices. The specimens were cut into $20 \mathrm{~mm}$ thick slices using a hacksaw. Each slice was then broken down into smaller parts for which the water content was determined by oven-drying method, whereas the volume was determined by molten wax method [26]. The dry density and the degree of saturation for each slice were then calculated from the volume-mass relationships.

\section{Test Results}

\subsection{Non-Isothermal Tests at Applied Temperatures of 85 and $150^{\circ} \mathrm{C}$}

Figures 2 and 3 present the measured temperature and relative humidity at predetermined depths of the compacted bentonite specimens for the non-isothermal tests that were carried out at temperatures of $85{ }^{\circ} \mathrm{C}$ (Tests T1 and T2) and $150{ }^{\circ} \mathrm{C}$ (Tests T3 and T4), respectively. For the sake of clarity in the presentation, the measured data in these plots during the initial test durations are not shown. The thickness of insulation used in the tests is shown in the legend of these plots.

The test results presented in Figures 2a and 3a show that the measured temperatures at all predetermined depths were greater in case of using a $40 \mathrm{~mm}$ thick insulation. Both the thickness of the insulation and the applied temperature influenced the temperature equilibrium time for the tests at $85^{\circ} \mathrm{C}$. Using $20 \mathrm{~mm}$ thick insulation (Test T1 in Figure 2a), the temperature at all predetermined depths 
were equilibrated within about 60 days, whereas the thermal equilibrium was reached within about 40 days for the test with a $40 \mathrm{~mm}$ thick insulation (Test T2 in Figure 2a). The thickness of insulation did not significantly influence the thermal equilibration time when the applied temperature was $150{ }^{\circ} \mathrm{C}$ (Figure 3a). For both Tests T3 and T4, the temperature at all predetermined depths equilibrated within about 80 days.

The test results presented in Figures 2a and 3a showed that the radial heat loss influenced the rise in the temperature within the bentonite specimens. A greater reduction in the heat loss was achieved by using a $40 \mathrm{~mm}$ thick insulation that was manifested in an increase in the temperature within the bentonite specimens.
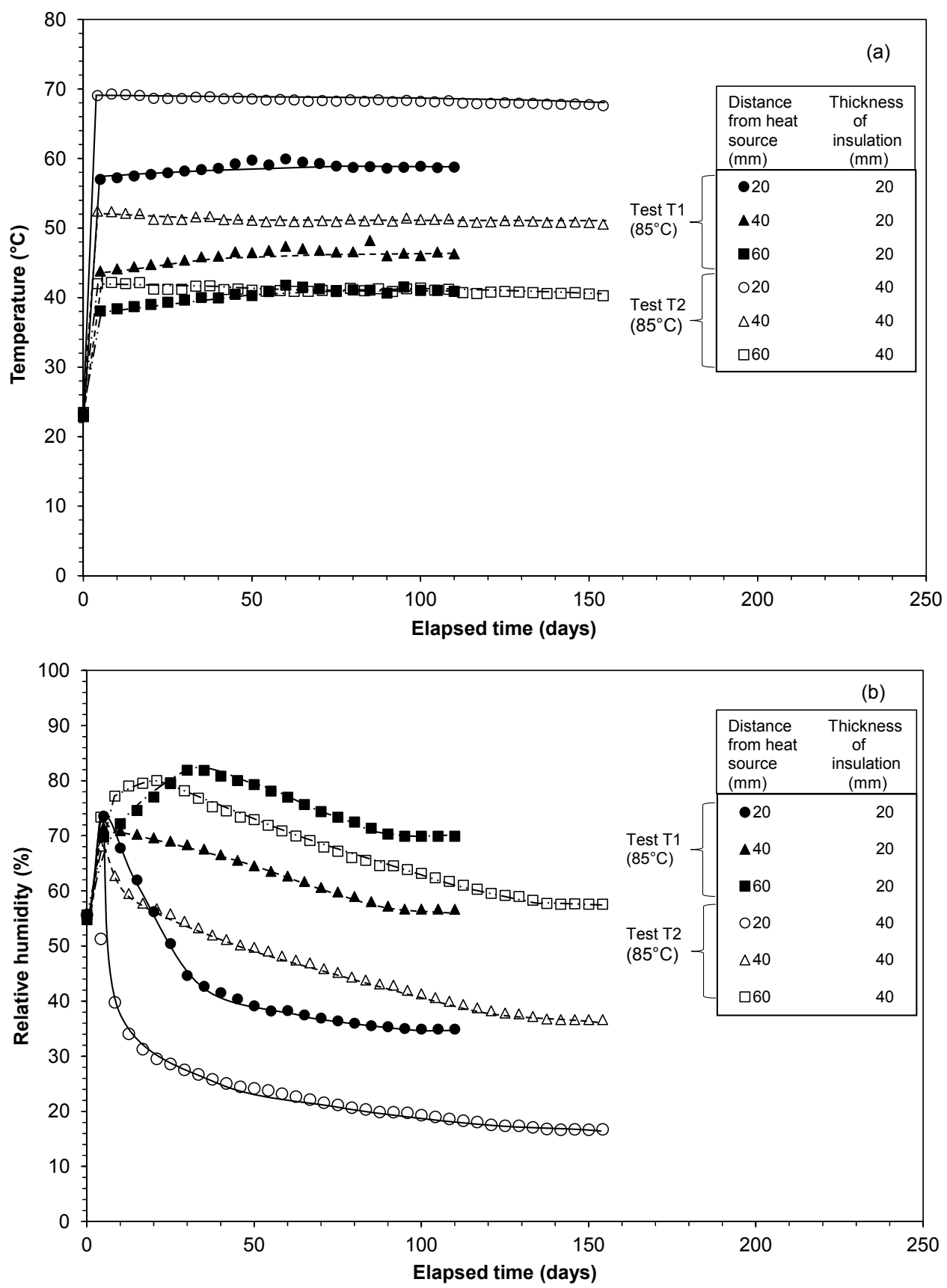

Figure 2. Effects of thermal gradient $\left(85{ }^{\circ} \mathrm{C}\right.$, bottom; and $25{ }^{\circ} \mathrm{C}$, top) on the distributions of: (a) temperature; (b) relative humidity in compacted bentonite specimens (diameter $100 \mathrm{~mm}$, height $80 \mathrm{~mm})$. 

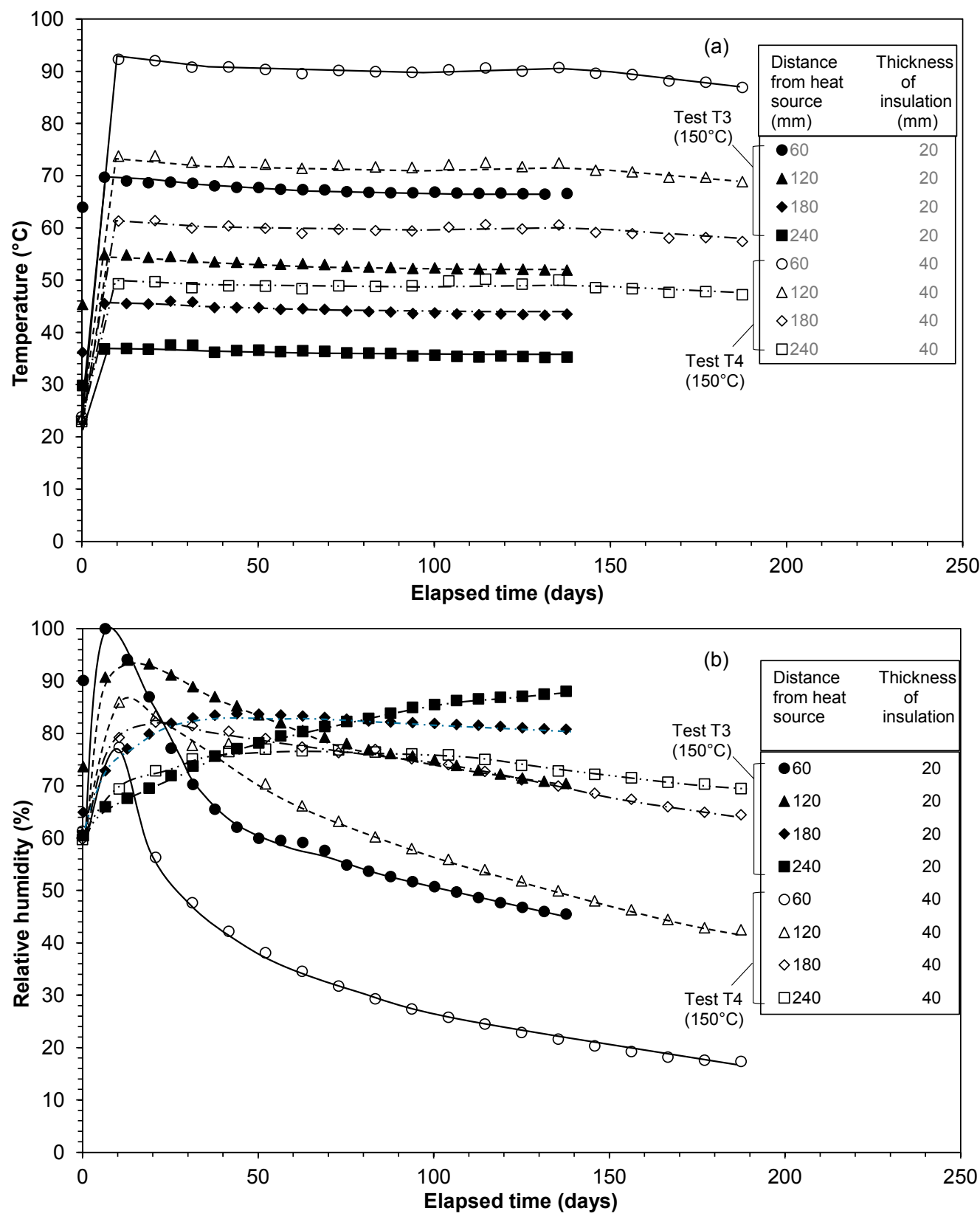

Figure 3. Effects of thermal gradient $\left(150{ }^{\circ} \mathrm{C}\right.$, bottom; and $25^{\circ} \mathrm{C}$, top) on the distributions of: (a) temperature; (b) relative humidity in compacted bentonite specimens (diameter $100 \mathrm{~mm}$, height $300 \mathrm{~mm})$.

The applied temperature and the thickness of insulation layer influenced the relative humidity equilibrium time (Figures $2 b$ and $3 b$ ). In general, the relative humidity increased and then decreased with an elapsed time at all predetermined depths, with an exception in case of Test T4 (applied temperature $=150{ }^{\circ} \mathrm{C}$ ), in which case the relative humidity increased with an elapsed time at distances of 180 and $240 \mathrm{~mm}$ from the heat source. For Tests T1 and T2 the relative humidity at all predetermined depths equilibrated within 95 and 142 days, respectively. The relative humidity at all predetermined depths in case of Tests T3 and T4 did not attain equilibrium for the duration of the tests considered in this study. The test results showed that a longer time may be required for the equilibration of the relative humidity when the applied temperature is $150{ }^{\circ} \mathrm{C}$. 


\subsubsection{Temperature Profiles in Non-Isothermal Tests}

Figure 4 shows the equilibrium temperature profiles for the bentonite specimens in Tests T1, T2, T3, and T4. The temperatures generated at various depths within the specimens for an applied temperature of $150{ }^{\circ} \mathrm{C}$ were greater than that occurred for an applied temperature of $85^{\circ} \mathrm{C}$. The differences between the temperatures in Tests $\mathrm{T} 1$ and $\mathrm{T} 2$ and in Tests T3 and T4 decreased with an increase in the distance from the heat source. The temperature profiles are generally found to be non-linear.

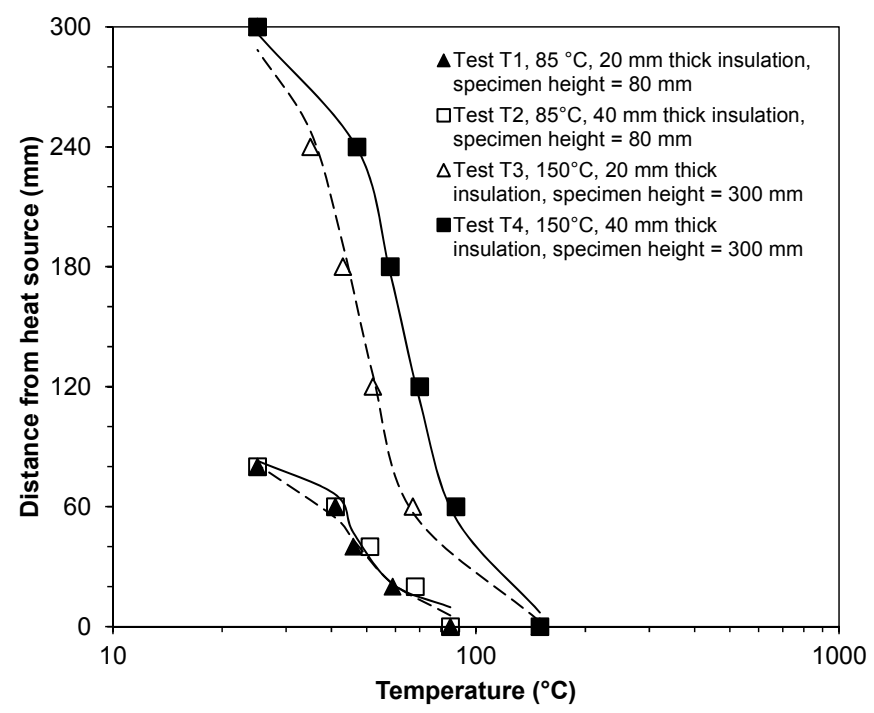

Figure 4. Temperature profiles in the non-isothermal tests at $85^{\circ} \mathrm{C}$ and $150{ }^{\circ} \mathrm{C}$ with various thicknesses of insulation.

Figure 5 shows the equilibrium temperature gradients within the specimens. It can be seen in Figure 5 that for the constant applied temperature gradients across the specimens $\left(-0.75{ }^{\circ} \mathrm{C} / \mathrm{mm}\right.$ and $-0.42{ }^{\circ} \mathrm{C} / \mathrm{mm}$ for applied temperatures of 85 and $150{ }^{\circ} \mathrm{C}$, respectively), there are differences in the gradients of temperature throughout the bentonite columns. The temperature gradient decreased as the distance from the heat source increased. The results show that heat flow within the bentonite columns under non-isothermal loading condition was not one-dimensional. The temperature gradients at various distances from the heat source remained between -1.3 and $-0.75^{\circ} \mathrm{C} / \mathrm{mm}$ for the specimens that were subjected to a temperature of $85^{\circ} \mathrm{C}$ (i.e., for Tests T1 and T2). Similarly, the temperature gradients for the specimens at various distances from the heat source in Tests T3 and T4 remained between -1.4 and $-0.42{ }^{\circ} \mathrm{C} / \mathrm{mm}$. Due to a reduction in the radial heat loss, at any distance from the heat source the temperature gradient for the tests with a $40 \mathrm{~mm}$ thick insulation was smaller (i.e., less negative). Comparing the temperature gradients in Tests T1 and T2 with Tests T3 and T4, it can be seen that for distances less than $60 \mathrm{~mm}$ from the heat source, an application of a temperature of $150{ }^{\circ} \mathrm{C}$ introduced higher temperature gradients in the compacted bentonite specimens. The profiles of thermal gradients in Figure 5 are expected to impact the moisture vapour redistribution within compacted bentonites. 


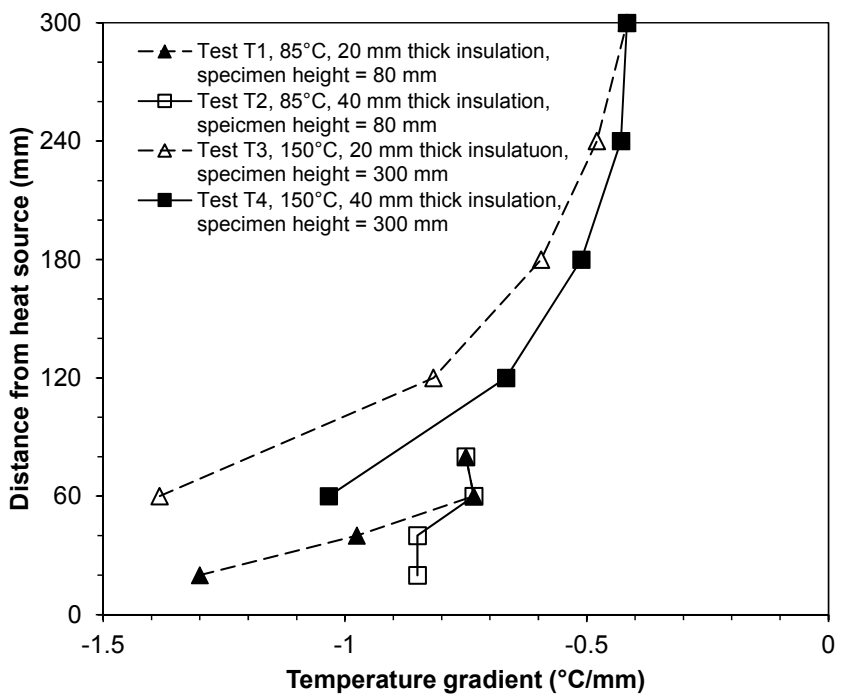

Figure 5. Temperature gradient at various distances from the heat source for non-isothermal tests at $85^{\circ} \mathrm{C}$ and $150^{\circ} \mathrm{C}$.

\subsubsection{Relative Humidity Profiles in Non-Isothermal Tests}

Figure 6 shows the relative humidity profiles of the bentonite specimens in Tests T1-T4. The relative humidity profiles correspond to the times at which the tests were terminated (Table 1). It can be seen from Figure 6 that the relative humidity within the specimens increased with an increase in the distance from the heat source indicating that a transfer of moisture vapour took place due to the application of the thermal gradients. For any applied temperature $\left(85^{\circ} \mathrm{C}\right.$ or $\left.150^{\circ} \mathrm{C}\right)$, the relative humidity at all distances from the heat source was greater for the tests that were conducted with a $20 \mathrm{~mm}$ thick insulation as compared to that of the tests with a $40 \mathrm{~mm}$ thick insulation.

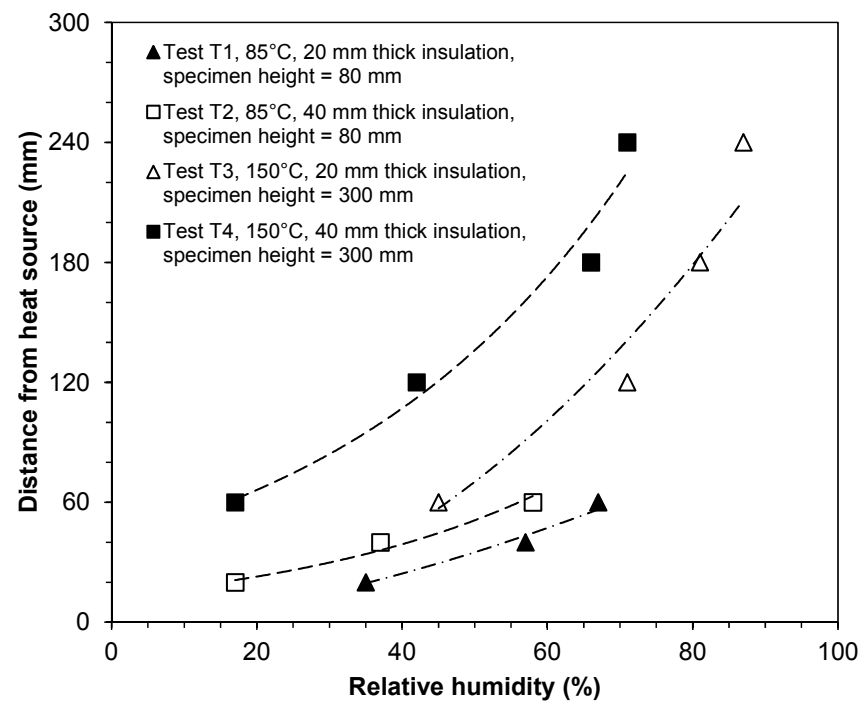

Figure 6. Relative humidity profiles in the non-isothermal tests at $85{ }^{\circ} \mathrm{C}$ and $150{ }^{\circ} \mathrm{C}$ with various thicknesses of insulation.

A higher temperature or a lower thermal gradient in case of using a $40 \mathrm{~mm}$ thick insulation (see Figures 4 and 5) is expected to cause more amount of moisture vapour transfer towards the top end of the specimens which in turn would tend to produce a higher relative humidity; however, this was not the case as noted from the relative humidity data (Figure 6). The relative humidity is known to be 
affected by the temperature. At any given amount of moisture vapour, an increase in the temperature causes a decrease in the relative humidity. Therefore, although the temperatures at the predetermined distances for the case of tests with $40 \mathrm{~mm}$ insulation were higher; however, the thermodynamic effects of a reduction in the relative humidity due to an increase in the temperature was manifested on the changes in the relative humidity of the specimens. The test results are consistent with the temperatures at various depths in that, at any depth, the higher the temperature, the lower the relative humidity was. The relative humidity profiles were found to be non-linear.

The test results clearly showed that the thermo-hydraulic response of compacted bentonites when subjected to temperature gradients under non-isothermal conditions depends upon the characteristics of materials surrounding the compacted bentonites. The thermal equilibrium generally occurred sooner (see Figures 2a and 3a) than the relative humidity equilibrium (Figure 3a,b).

Differences in the temperature gradient and the relative humidity can be noted at all depths of the specimens (Figure 7). An increase in the temperature gradient nearer to the heat source caused evaporation of water leading to a decrease in the relative humidity, whereas a decrease in the temperature gradient away from the heat source caused condensation, leading to an increase in the relative humidity within the compacted bentonite specimens.

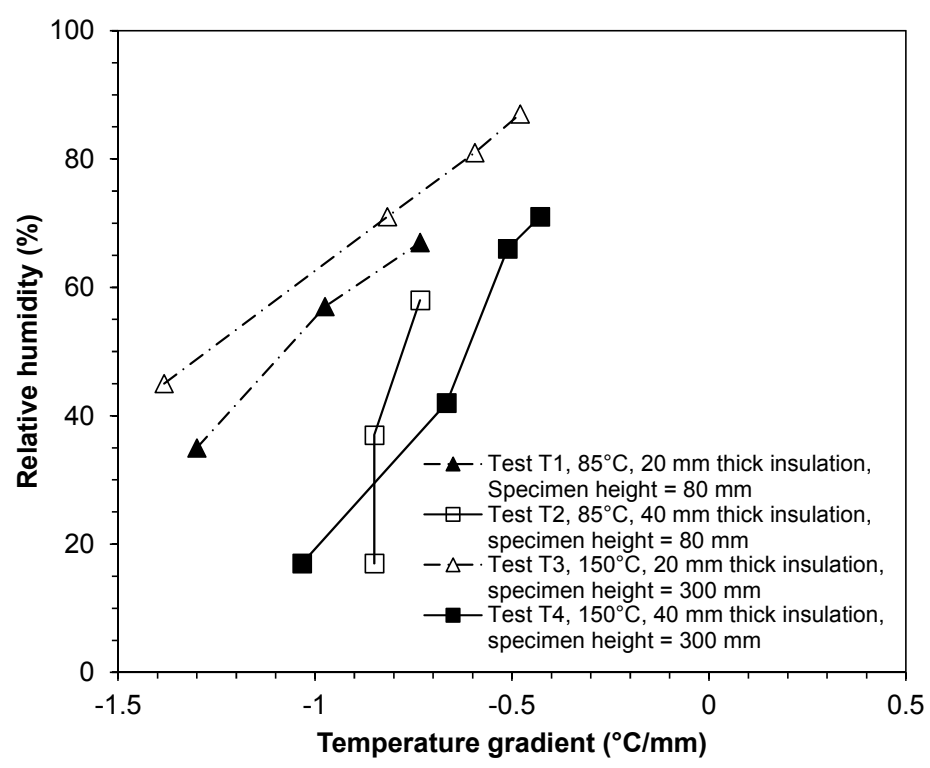

Figure 7. Temperature gradient versus relative humidity plot for non-isothermal tests at $85{ }^{\circ} \mathrm{C}$ and $150{ }^{\circ} \mathrm{C}$.

\subsection{Non-Isothermal Hydraulic Tests at Applied Temperatures of $85^{\circ} \mathrm{C}$ and $150^{\circ} \mathrm{C}$}

Figures 8 and 9 present the measured temperature and relative humidity at predetermined depths of the specimens for the non-isothermal hydraulic tests. In Tests TH5 and TH6, the temperature at all predetermined depths equilibrated within about 150 days. The impact of a thicker outer insulation was to generate a higher temperature at all predetermined depths of the specimens. The difference between the temperature equilibration time between TH7, TH8 and TH9 was found to be indistinct indicating that the water injection pressure had no significant bearing on the temperature equilibration time for these tests. The temperature equilibrium at all predetermined depths in these cases occurred after about 50 days. Comparing the temperature equilibration for non-isothermal tests (Tests T2 and T4) and non-isothermal hydraulic tests (Tests TH6 to TH9), it can be noted that at any applied temperature $\left(85^{\circ} \mathrm{C}\right.$ or $\left.150^{\circ} \mathrm{C}\right)$, the impact of simultaneous applications of thermal and hydraulic gradients increased the temperature equilibration time for the tests at $85^{\circ} \mathrm{C}$ (from 40 to 150 days), whereas it decreased for the tests at $150{ }^{\circ} \mathrm{C}$ (from 80 to 50 days). 

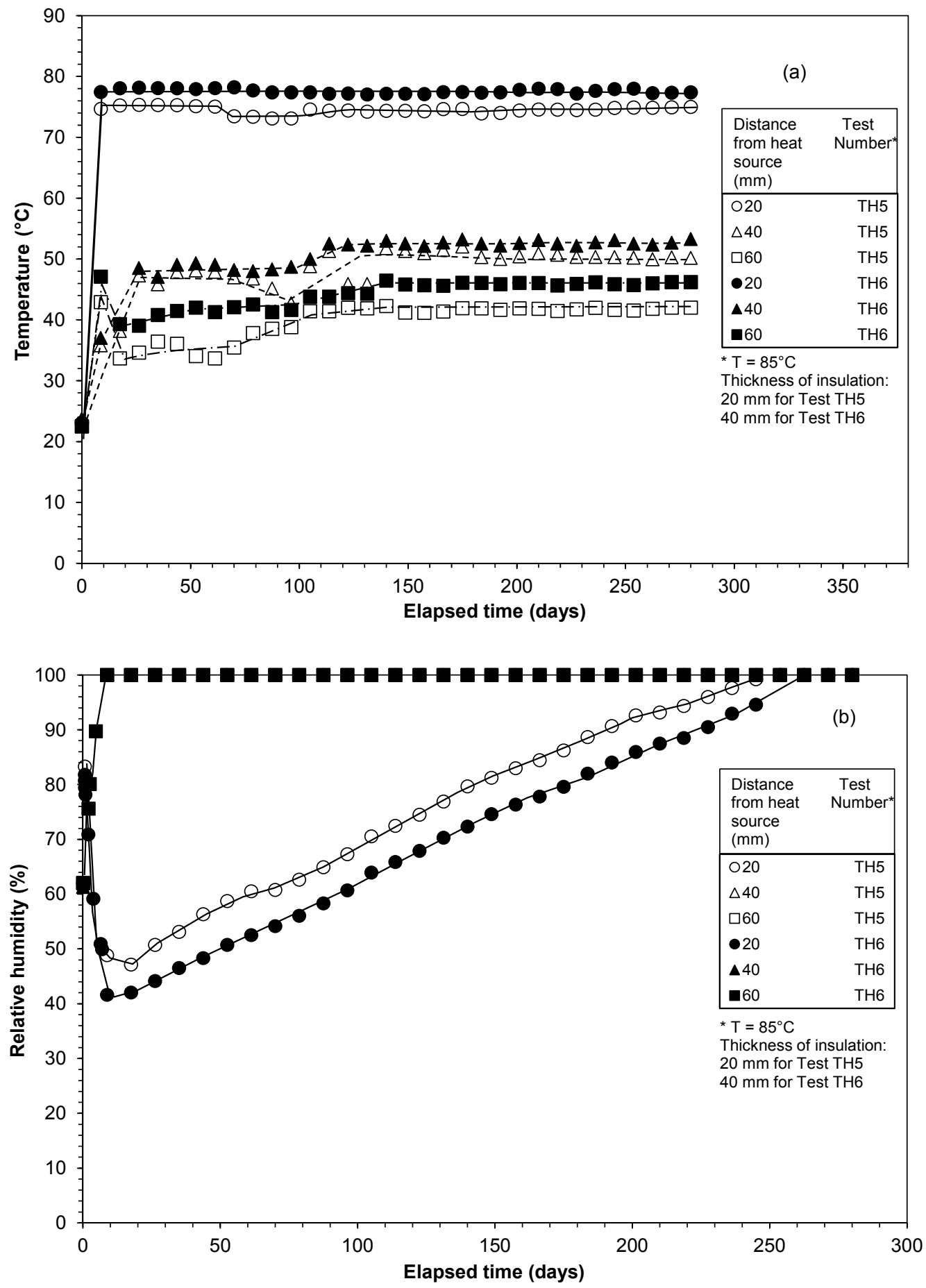

Figure 8. Effects of simultaneous application of thermal and hydraulic gradients $\left(85^{\circ} \mathrm{C}\right.$, bottom; $25^{\circ} \mathrm{C}$, top; and water pressure from top $=600 \mathrm{kPa}$ ) on the distributions of: (a) temperature; (b) relative humidity in compacted bentonite specimens (diameter $100 \mathrm{~mm}$, height $80 \mathrm{~mm}$ ). 

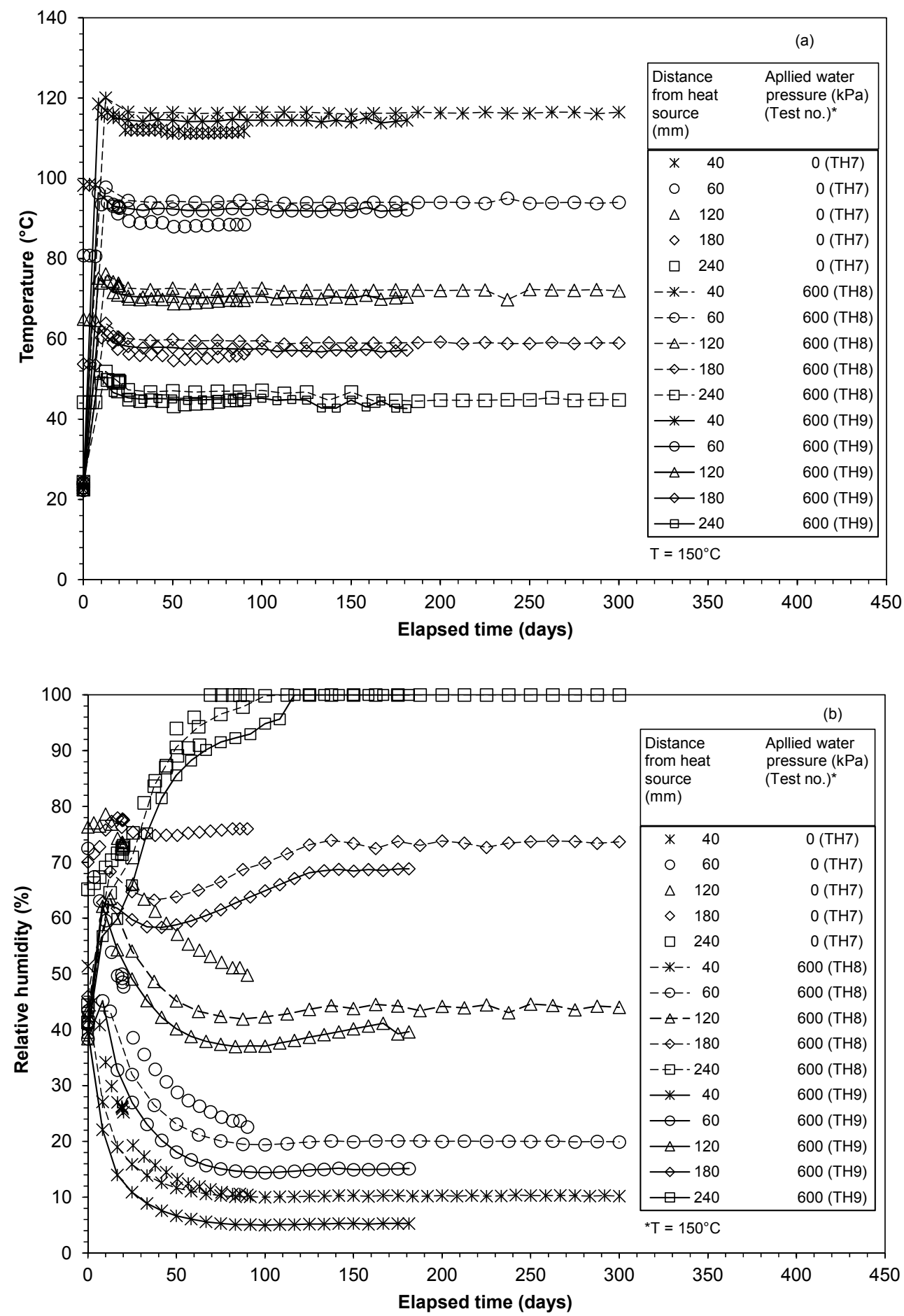

Figure 9. Effects of simultaneous thermal and hydraulic gradients $\left(85^{\circ} \mathrm{C}\right.$, bottom; and $25^{\circ} \mathrm{C}$, top; and water pressure from top $=600 \mathrm{kPa}$ or $5 \mathrm{kPa}$ ) on the distributions of: (a) temperature; (b) relative humidity in compacted bentonite specimens (diameter $100 \mathrm{~mm}$, height $300 \mathrm{~mm}$ ).

The relative humidity increased and further decreased with an elapsed time at distances closer to the heat source, whereas it increased at distances away from the heat source. The relative humidity equilibrated at all predetermined depths for the specimens in Tests TH5 to TH9 with an exception of Test TH7. At distances of 40 and $60 \mathrm{~mm}$ from the heat source, the relative humidity of the specimens in Tests TH5 and TH6 was found to be $100 \%$ within about seven days, whereas it occurred after 250 
days at a distance of $20 \mathrm{~mm}$. The relative humidity was found to be $100 \%$ at a distance of $240 \mathrm{~mm}$ for the specimens in Tests TH8 and TH9, whereas at all other depths the relative humidity remained less than $100 \%$.

\subsubsection{Temperature Profiles in Non-Isothermal Hydraulic Tests}

Figure 10 shows the equilibrium temperature against distance of the temperature probes from the heat source. The temperature profiles for Tests TH5 and TH6 were found to be very similar indicating that the thickness of insulation had very minor influence on the temperature profile. Similarly, the temperature profiles for Tests TH7, TH8, and TH9 were found to be very similar indicating that the influence of water injection pressure and the test durations did not influence the temperature profile significantly. A higher applied temperature generated greater temperature in the specimens. Comparing the temperatures at various depths for the non-isothermal and non-isothermal hydraulic tests under similar conditions of applied temperature and thickness of the insulation, it was noted that except at locations closer to the heat source where the temperatures in case of hydraulic tests were slightly greater, at all other depths the temperatures generated within the specimens were very similar.

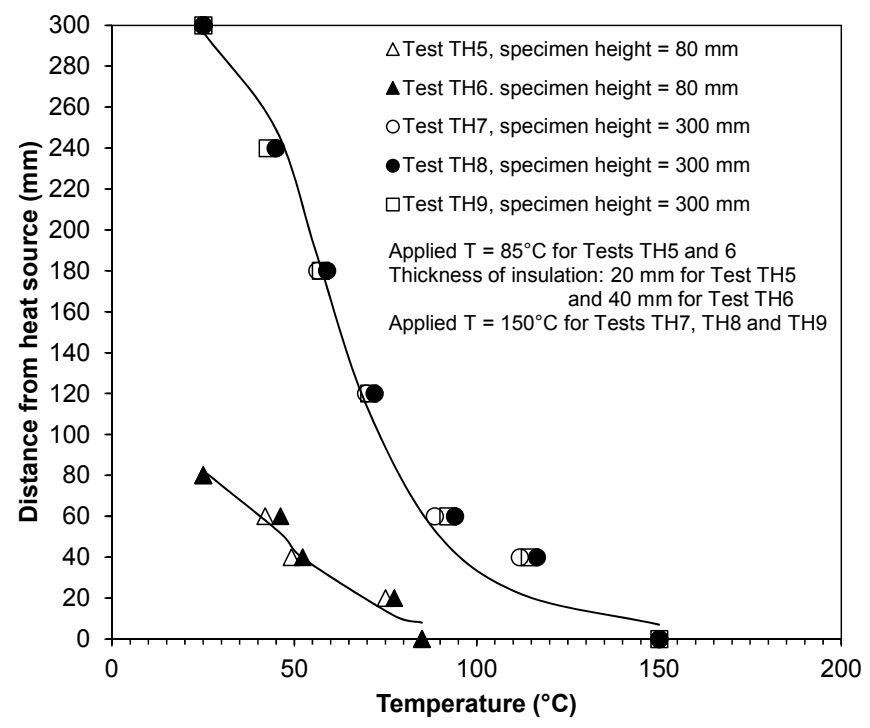

Figure 10. Temperature profiles in the non-isothermal hydraulic tests at $85^{\circ} \mathrm{C}$ and $150{ }^{\circ} \mathrm{C}$.

Figure 11 presents the temperature gradients at various salient depths of the specimens for Tests TH5 to TH9. It can be seen in Figure 11 that the temperature gradient increased and further decreased as the distance from the heat source increased. Comparing the temperature gradients in the thermo-hydraulic tests and the thermal tests (Figure 5), it can be noticed that the thermal gradients remained similar at distances away from the heat source. The smaller values of the temperature gradients at a distance of $40 \mathrm{~mm}$ from the heat source for Tests $\mathrm{TH} 7, \mathrm{TH} 8$, and TH9 are due primarily to the high temperature effect. Note that measurements of the temperature at a distance of $40 \mathrm{~mm}$ were not carried out in case of Tests T3 and T4. For Tests TH5 and TH6, the smaller values of temperature gradients at a distance of $20 \mathrm{~mm}$ are attributed to an increase in the water content in the specimens as shown by the relative humidity data (Figure $8 \mathrm{~b}$ ). The temperature gradient remained between -0.89 and $-0.38{ }^{\circ} \mathrm{C} / \mathrm{mm}$ for the tests at $85^{\circ} \mathrm{C}$, whereas it remained between -1.05 and $-0.42{ }^{\circ} \mathrm{C} / \mathrm{mm}$ for the tests at $150{ }^{\circ} \mathrm{C}$. 


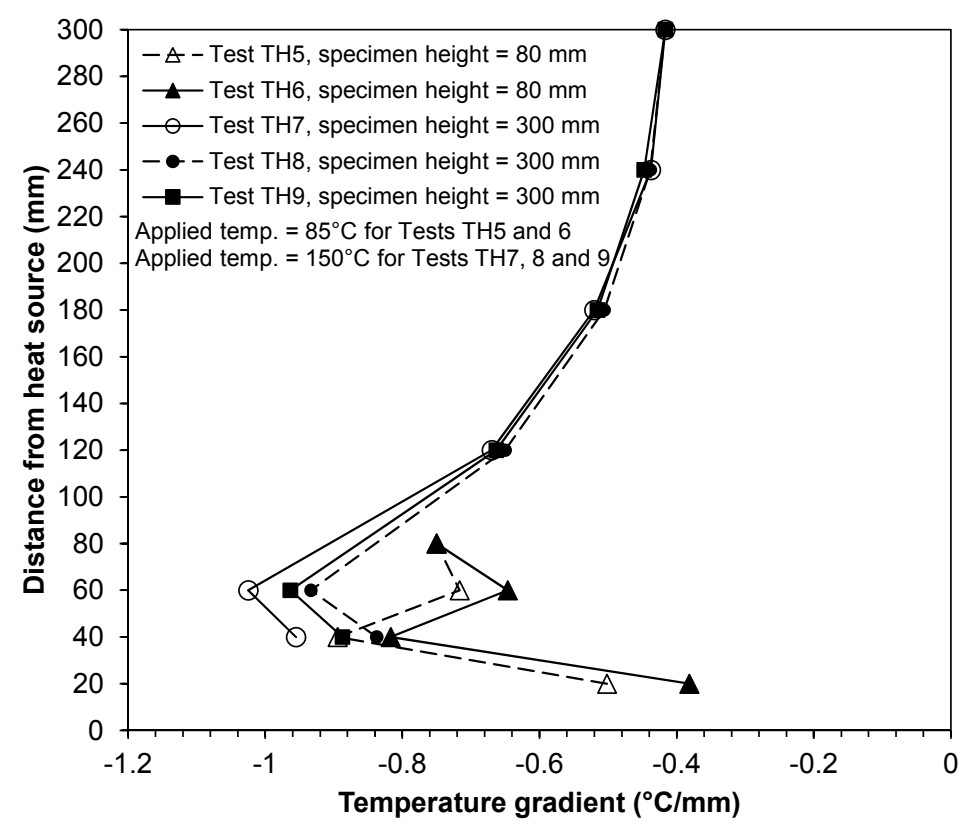

Figure 11. Temperature gradient at various distances from the heat source for non-isothermal hydraulic tests at $85^{\circ} \mathrm{C}$ and $150^{\circ} \mathrm{C}$.

\subsubsection{Relative Humidity Profiles in Non-Isothermal Hydraulic Tests}

Figure 12 shows the relative humidity values recorded prior to termination of the tests. The relative humidity in case the specimens tested at a temperature of $85^{\circ} \mathrm{C}$ reached $100 \%$ at the end of the tests and hence the results are not included in Figure 12. The thermal and hydraulic gradients influenced the evolution of the relative humidity profiles. The relative humidity increased with an increase in the distance from the heat source. The durations of tests and the applied water pressures did not significantly influence the relative humidity profiles. The relative humidity profiles were found to be linear.

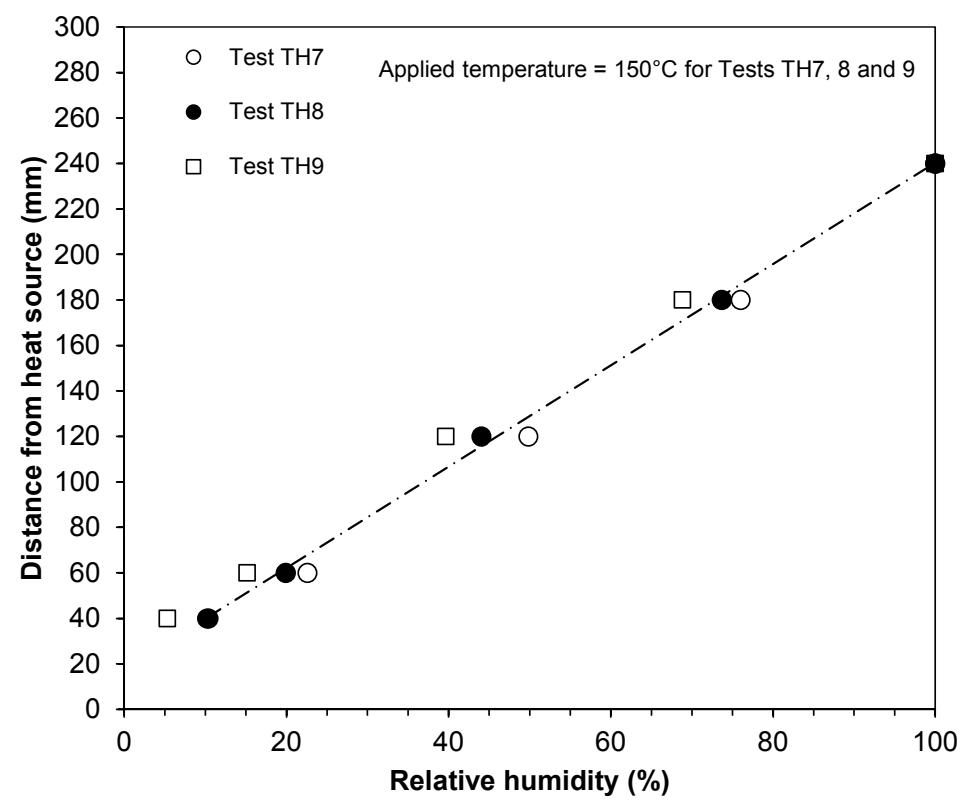

Figure 12. Relative humidity profiles in the non-isothermal hydraulic tests at $150{ }^{\circ} \mathrm{C}$. 


\subsection{Shapes of Temperature and Relative Humidity Profiles}

The shapes of temperature profiles presented in Figures 4 and 10 are found to be similar to an inverted $S$-shaped curve. The experimental data presented in Figures 4 and 10 were best-fitted with a two-parameter model (Equation (1)) as shown in Figures 4 and 10. The fitting parameters are shown in Table 2.

$$
D=\frac{D_{\max }}{\left[1+\left\{a(T)^{b}\right\}\right]^{\left(1-\frac{1}{b}\right)}}
$$

where $D$ is the distance from the heat source, $D_{\max }$ is thickness of bentonite, $a$ and $b$ are the fitting parameters, and $T$ is the temperature at a distance of $D$ from the heat source.

Table 2. Model fitting parameters for temperature profiles.

\begin{tabular}{cccccc}
\hline \multirow{2}{*}{ Test No. } & Type of Test & $\begin{array}{c}\text { Height of Specimen } \\
(\mathbf{m m})^{\mathbf{1}}\end{array}$ & $\begin{array}{c}\text { Temperature at } \\
\text { Bottom/Top }\left({ }^{\circ} \mathbf{C} /{ }^{\circ} \mathbf{C}\right)\end{array}$ & \multicolumn{2}{c}{ Model Parameters } \\
\cline { 5 - 6 } & & 80 & $85 / 25$ & 0.023 & 5 \\
T1 & Non-isothermal & 80 & $85 / 25$ & 0.020 & 5 \\
T2 & 300 & $150 / 25$ & 0.022 & 5 \\
T3 & 300 & $150 / 25$ & 0.017 & 5 \\
T4 & & 80 & $85 / 25$ & 0.021 & 5 \\
TH5 & Non-isothermal & 80 & $85 / 25$ & & \\
TH6 & hydraulic & 300 & $150 / 25$ & & 5 \\
TH7 & & $150 / 25$ & 0.017 & 5 \\
TH8 & & $150 / 25$ & & \\
TH9 & & 300 &
\end{tabular}

${ }^{1}$ Diameter of specimen $=100 \mathrm{~mm} \cdot a$ and $b$ : fitting parameters.

The value of the parameter $a$ decreased for an increase in the thickness of insulation, an increase in the temperature, an increase in the thickness of bentonite, and for the hydraulic tests. The value of the parameter $b$ remained unchanged. Equation (1) can be used to calculate the distance at which an anticipated temperature will prevail.

The shapes of relative humidity profiles for non-isothermal and non-isothermal hydraulic tests (Figures 6 and 12) are found to be dissimilar. A generalized two parameter model (Equations (2)) was used to best-fit the relative humidity profiles, as shown in Figure 6. The model parameters are shown in Table 3. In all cases, very high values of the coefficients of regression were found. Equation (2) can be used to estimate the distance at which a specific value of the relative humidity will prevail or the relative humidity at any distance from the heat source. The parameters shown in Table 3 are for the duration of the tests considered in this study and hence may not be reliable for calculating the relative humidity at equilibrium conditions for the non-isothermal applied boundary condition. The relative humidity profiles for Tests TH7, TH8, and TH9 (Figure 12) were best fitted with a linear relationship (Equation (3)).

$$
\begin{aligned}
R H_{D} & =\frac{1}{n} \log _{e}\left(\frac{D}{m}\right) \\
R H_{D} & =\left[\frac{D-17.71}{2.23}\right]
\end{aligned}
$$

where $m$ and $n$ are the best-fit parameters and $R H_{\mathrm{D}}$ is the relative humidity at a distance of $D$ from the heat source. 
Table 3. Model parameters for the relative humidity profiles in non-isothermal tests.

\begin{tabular}{ccc}
\hline \multirow{2}{*}{ Test No. } & \multicolumn{2}{c}{ Model Parameters } \\
\cline { 2 - 3 } & $\boldsymbol{m}$ & $\boldsymbol{n}$ \\
\hline T1 & 6.0375 & 0.0339 \\
T2 & 13.296 & 0.0267 \\
T3 & 13.559 & 0.0321 \\
T4 & 40.950 & 0.0240 \\
\hline
\end{tabular}

$m$ and $n$ : best-fit parameters.

The experimental data of MX80 bentonite reported by Villar et al. [17] were considered for comparing with the model results in this study. Villar et al. [17] carried out laboratory tests on MX80 bentonite (70 mm diameter and $500 \mathrm{~mm}$ high) with initial dry density and water content of $1.53 \mathrm{Mg} / \mathrm{m}^{3}$ and $6.4 \%$, respectively. The applied temperature at the base of the specimen was $140{ }^{\circ} \mathrm{C}$. Following the heating phase for about 239 days, the specimen was hydrated with water from the opposite end of the heat source with an injection pressure of $6.0 \mathrm{kPa}$. Figure 13a,b show the temperature and relative humidity profiles for the non-isothermal and non-isothermal hydraulic phases of the test, respectively. The experimental data for the simultaneous heating and hydration phase correspond to a test duration of 620 days. The calculated results for the temperature and relative humidity are shown in Figure 13. It can be seen that the model results in this study generally predicted higher values of the temperature and the relative humidity; however, the shapes of the profiles are captured well. The difference in the experimental and calculated results originate from the differences in the initial compaction conditions, the applied temperature, the size of specimen, the insulation type used, and the duration of the tests.

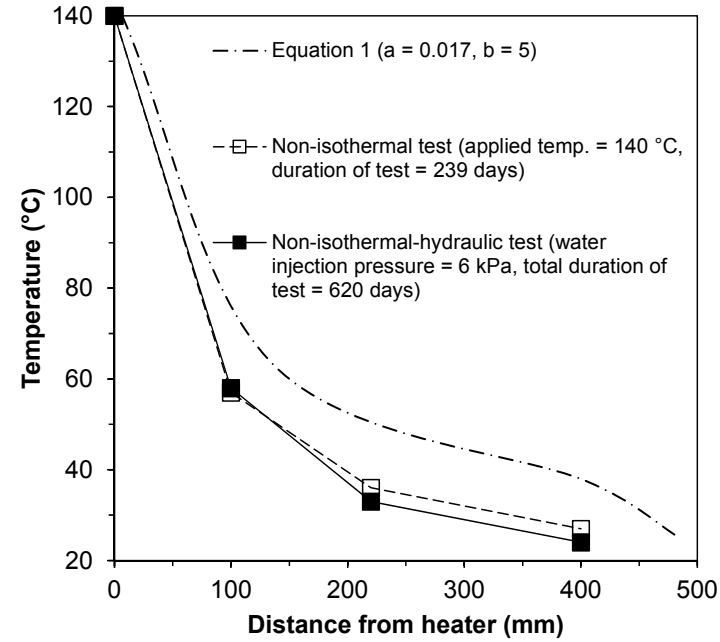

(a)

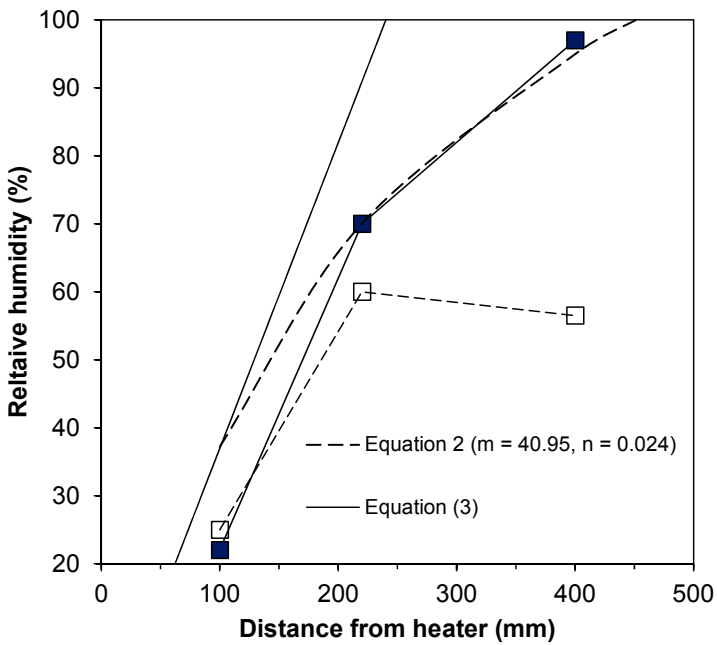

(b)

Figure 13. Comparison of test results from the literature [17] and model results in this study for: (a) temperature profiles; (b) relative humidity profiles.

\subsection{Development of Axial Stress during Non-Isothermal and Non-Isothermal Hydraulic Tests}

Figure 14 shows the elapsed time versus the measured axial stress for the compacted bentonite specimens tested in this study. Due to a technical fault in the load cell, the axial stress in Test T3 at $150{ }^{\circ} \mathrm{C}(20 \mathrm{~mm}$ thick insulation) could not be recorded. 


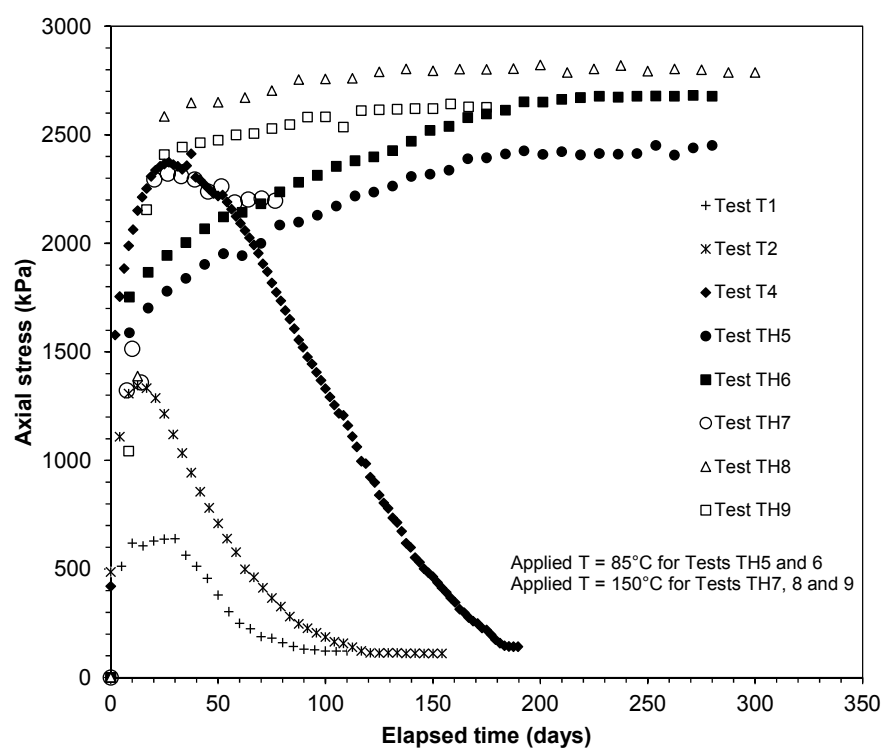

Figure 14. Development of axial stress due to applied thermal and thermo-hydraulic gradients.

The axial stress is found to increase and then decrease for the non-isothermal tests (Tests T1, $\mathrm{T} 2$, and $\mathrm{T} 4$ ), whereas it increased and attained equilibrium with elapsed time for the non-isothermal hydraulic tests (Tests TH5 to TH9). The maximum measured axial stress for the specimens in Tests T1, $\mathrm{T} 2$, and T4 were 640,1345 and $2400 \mathrm{kPa}$, respectively. The corresponding equilibrium axial stresses were 120, 115 and $145 \mathrm{kPa}$. The differences in the maximum axial stress are attributed to the applied temperature and the thickness of the insulation layer used. The measured total axial stresses for the specimens in Tests TH5, TH6, TH7, TH8, and TH9 were 2680, 2450, 2200, 2630, and $2800 \mathrm{kPa}$, respectively. Villar et al. [17] reported similar magnitudes of axial stress for MX80 bentonite at an applied temperature of $140^{\circ} \mathrm{C}$.

Tripathy et al. [18] stated that an increase and further decrease in the axial stress exhibited by compacted bentonite specimens due to an application of a thermal gradient is attributed to the combined influence of several factors, such as (1) water vapour movement from the hotter to the cooler end of the specimen, (2) volumetric shrinkage of the specimen towards the heater end due to an increase in the temperature and movement of moisture from the hotter to the cooler end, (3) compression of the specimen due to the development of the axial pressure, (4) expansion of the specimens due to an increase in the temperature for the layers having high suctions, (5) contraction of layers due to an increase in the temperature for the layers with low suctions, (6) expansion of the testing device upon an increase in the temperature, and (7) migration and redistribution of moisture to farther distances in order to equalize the suction (usually from top to bottom).

From the test results of profiles of the temperature and the relative humidity (Figures 4 and 6), it becomes clear that under non-isothermal conditions, an increase in the temperature, either due to the use of a thicker insulation or due to an application of a higher temperature, causes a decrease in the relative humidity within the compacted bentonite specimens. From the consideration of the relative humidity increase in compacted bentonites during the hydration process and its impact on axial thrust development, it was anticipated that specimens with a higher relative humidity would tend exhibit a greater axial stress. However, a reverse trend was noted in the test results; the specimens with a lower relative humidity exhibited greater maximum axial stress (Test T1 versus Test T2 or Test T2 versus Test T4 in Figures 6 and 12). Therefore, the hydration mechanism cannot be held solely responsible for axial stress development in compacted bentonites under non-isothermal conditions. Other issues, such as moisture redistribution due to thermal and suction gradients, thermal expansion of bentonite, gas pressure generation, and thermal expansion of the specimen cell may contribute to the axial stress 
development. The test results also indicate that the equilibrium axial stress in compacted bentonites when subjected to thermal loading was not influenced by the applied thermal gradient. All three specimens exhibited near similar axial stress at equilibrium.

The difference in the applied temperature $\left(85^{\circ} \mathrm{C}\right.$ and $\left.150{ }^{\circ} \mathrm{C}\right)$ and the hydraulic boundary conditions influenced the development of the axial stress. The axial stress in compacted bentonites for thermo-hydraulic boundary condition remained between 2.0 to $3.0 \mathrm{MPa}$. This suggests that, thermo-hydraulic gradient effects are more pronounced in the axial stress development in compacted bentonites under restrained condition. Additionally, applications of temperatures of $85^{\circ} \mathrm{C}$ and $150{ }^{\circ} \mathrm{C}$ caused changes in terms of thermal gradient and relative humidity; however, their impact on the evolution of axial stress remained small.

\subsection{Profiles of Water Content, Dry Density, Degree of Saturation and Suction}

The water content, dry density, and degree of saturation data presented in Figures 15 and 16 are based on analyses of the samples of bentonite slices $(20 \mathrm{~mm}$ thick) after termination of the tests. The suction data presented in Figures 15 and 16 are based on the recorded relative humidity and temperature at the end of each test. The suctions were calculated based on the thermodynamic relationship between the relative humidity and suction.
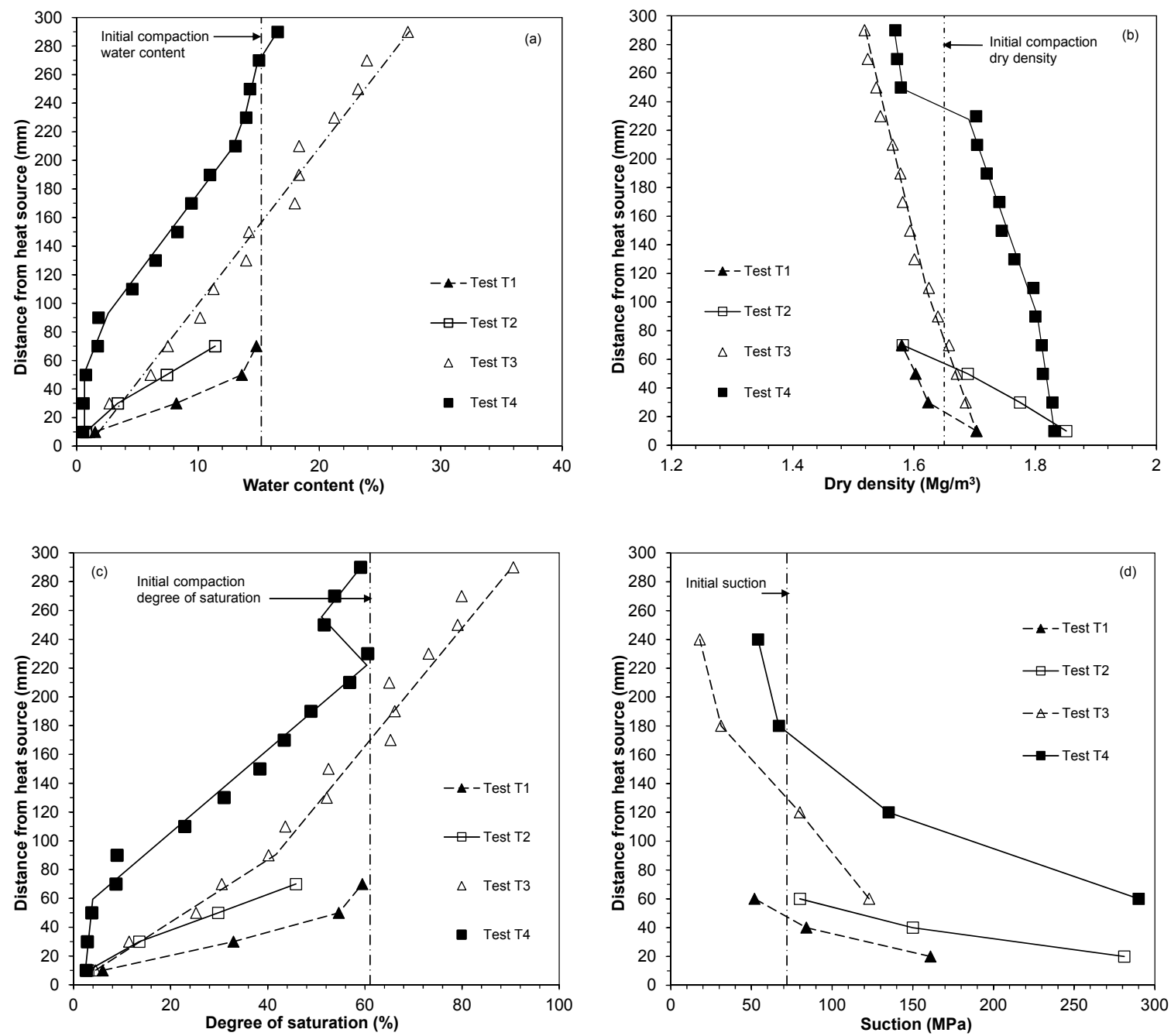

Figure 15. Profiles of: (a) water content; (b) dry density; (c) degree of saturation; (d) suction, for non-isothermal tests at $85^{\circ} \mathrm{C}$ and $150{ }^{\circ} \mathrm{C}$. 

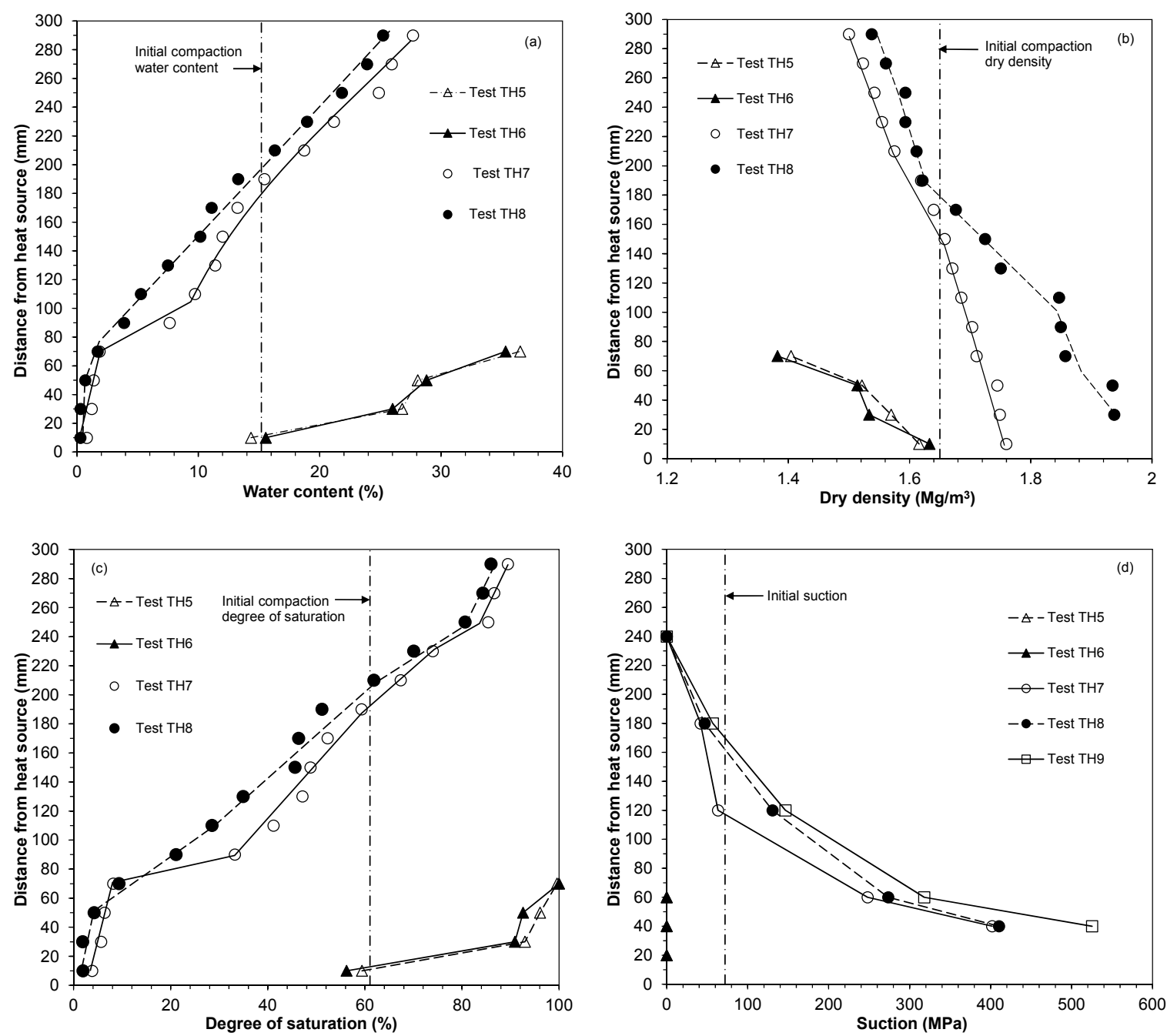

Figure 16. Profiles of: (a) water content; (b) dry density; (c) degree of saturation; (d) suction, for non-isothermal hydraulic tests at $85^{\circ} \mathrm{C}$ and $150{ }^{\circ} \mathrm{C}$.

The results presented in Figures 15 and 16 indicate two distinct aspects, such as (i) towards the opposite end of the heat source, the bentonite specimens underwent a wetting process as indicated by an increase in the water content, a decrease in the dry density, an increase in degree of saturation, and a decrease in suction and (ii) towards the heat source the specimens underwent a shrinkage process as indicated by a decrease in the water content, an increase in the dry density, a decrease in the degree of saturation and an increase in suction.

For the non-isothermal test results shown in Figure 15, the water content and degree of saturation at all salient levels in Test 2 remained smaller than Test 1 . Similarly, the water content and degree of saturation at all salient levels in Test 4 remained smaller than Test 3 . The degree of saturation for the non-isothermal tests remained below 100\% indicating that the bentonite specimens remained unsaturated. The test results presented in Figure 15 in terms of the water content, dry density, degree of saturation, and suction complement well the results presented in Figures 4 and 6 in terms of the profiles of temperature and relative humidity. For example, consider either Tests T1 and T2 or T3 and T4. At any given distance from the heat source, the specimens tested with a $40 \mathrm{~mm}$ thick insulation had lower relative humidity as compared to that of the specimens tested with a $20 \mathrm{~mm}$ thick insulation. The water content was found to be lower in case of Test T2 than T1 and lower for Test T4 than T3. The suction profiles that were established from the relative humidity and temperature profiles of the specimens agree well with the water content and degree of saturation profiles (Figure 15a,c). 
For the non-isothermal hydraulic tests, the difference between the results for Tests TH7 and TH8 are only marginal in terms of the water content. In spite of the shrinkage of the specimens in Tests TH7 and TH8, the axial stress did not decrease (Figure 14). This may be attributed to an expansion of the specimens upon wetting at the top part. Comparing the test results presented in Figures 15 and 16, it can be noticed that the impact of hydraulic gradient was to cause an overall increase in the water content and degree of saturation within the compacted bentonite specimens.

\section{Discussion}

High density compacted bentonites have been proposed to form the buffer surrounding the waste canisters in the underground nuclear waste repositories. The buffer will be subjected to both thermal and hydraulic loadings in certain situations. Therefore, well-controlled laboratory tests involving simultaneous applications of thermal and hydraulic loadings or only thermal loading provide information that play crucial roles for understanding the behaviour of bentonites in terms of their efficiencies in satisfying the hydraulic, mechanical, thermal, and chemical criteria set out for the safety of the underground nuclear waste repositories [4]. The laboratory test results have enabled validating numerical models for assessing the short and long-term behaviour of the engineered barrier systems $[27,28]$.

The heat flow through soil systems is complex due to the fact that the thermal conductivity of soil increases with an increase in the dry density, decreases with an increase in the porosity, and increases with an increase in the water content and degree of saturation [29]. The host rock will provide the physical confinement to the bentonite buffer. Therefore, in addition to various factors the thermal and hydraulic properties of the host rock to some extent will govern the temperature and water content distributions within the buffer.

Both during the early-life and late-life phases of the repositories, the stress, thermal, and hydraulic boundary conditions surrounding compacted bentonites may change, which in turn may impact the thermal and hydraulic responses of compacted bentonites. In the past, research works have been focused in exploring the thermo-hydro-mechanical response of compacted bentonites for applied temperatures of less than $100^{\circ} \mathrm{C}$. In this study, compacted bentonites were subjected to both thermal and thermo-hydraulic gradients to explore the impact of high temperatures $\left(85^{\circ} \mathrm{C}\right.$ and $\left.150{ }^{\circ} \mathrm{C}\right)$ on the thermo-hydro-mechanical behaviour.

The test results clearly showed that the thermal response of compacted bentonites when subjected to temperature gradients depends upon the magnitude of applied temperature and the thermal conductivity of the surrounding material (i.e., thermal insulation). Similarly, the impact of thermo-hydraulic gradient at an applied temperature, and the impact of an elevated temperature on the thermo-hydraulic response of compacted bentonites could be derived from the test results. The main findings from this study are summarised in Tables 4 and 5.

Table 4. Impact of improved thermal insulation and high temperature effects for non-isothermal loading on compacted bentonites.

\begin{tabular}{ccc}
\hline \multirow{2}{*}{ Factors } & \multicolumn{2}{c}{ Remarks } \\
\cline { 2 - 3 } & Improved Thermal Insulation & High Temperature \\
\hline Temperature & Increases & Increases \\
Temperature equilibration time & Decreases & Decreases \\
Relative humidity & Decreases & Decreases \\
Relative humidity equilibration time & Increases & Increases \\
Water absorption & Decreases & Decreases \\
Dry density & Increases & Increases \\
Degree of saturation & Decreases & Decreases \\
Suction & Increases & Increases \\
Axial stress & No significant effect & No significant effect \\
\hline
\end{tabular}


Table 5. Impact of thermo-hydraulic loading on compacted bentonites.

\begin{tabular}{ccc}
\hline & \multicolumn{2}{c}{ Remarks } \\
\cline { 2 - 3 } Factors & $\begin{array}{c}\text { As Compared to Applied } \\
\text { Thermal Loading }\end{array}$ & $\begin{array}{c}\text { High Temperature Effects in } \\
\text { Thermo-Hydraulic Loading }\end{array}$ \\
\hline Temperature & Very similar & Increases \\
Temperature equilibration time & Inconclusive & Decreases \\
Relative humidity & Increases & Decreases \\
Relative humidity equilibration time & Decreases & Increases \\
Drying & Reduces & Increases \\
Wetting & Increases & Reduces \\
Axial stress & Increases & Minor effect \\
\hline
\end{tabular}

Table 4 presents the impact of thermal insulation and higher temperature (i.e., when the applied temperature was increased from $85^{\circ} \mathrm{C}$ to $150{ }^{\circ} \mathrm{C}$ ) on a variety of factors within compacted bentonites. Table 5 shows the changes that may occur for various factors due to a simultaneous application of thermal and hydraulic loadings as compared to that of the thermal loading, and the impact of higher temperature when thermo-hydraulic loading condition is considered as a reference.

Table 4 shows that both the improved thermal insulation and high temperature application have the same influence on the various factors within compacted bentonites. The findings presented in Table 4 and Figure 15 suggest that thermal loading with improved insulation may cause an increase the shear strength of bentonite due to an increase in the dry density towards the warmer regions (i.e., towards the heat source), whereas a reverse trend can be expected at the opposite end. The development of axial stress occurs (Figure 14), but of a small magnitude (about $125 \mathrm{kPa}$ ), primarily due to the wetting that occurs at the opposite end of the heat source (see Figure 15). The dissipation of heat from compacted bentonites (in this case $20 \mathrm{~mm}$ thick insulation) may cause superior hydration, which in turn will cause a decrease in the hydraulic conductivity due to an increase in the water content (see Figure 15). In both cases, an impermeable zone is expected to form at the interface between the host rock and buffer which will aid in retarding the transport of radionuclides.

Table 5 shows that thermo-hydraulic loading at any applied thermal gradient have several advantages, for example, an increase in the water content causes a decrease in the hydraulic conductivity and an increase in the axial stress. The effect of high temperature $\left(150{ }^{\circ} \mathrm{C}\right)$ although caused an overall decrease in the water content and degree of saturation; however, the axial stress remained similar to that occurred in case of a lower temperature $\left(85^{\circ} \mathrm{C}\right)$. This suggests that the stability of the underground repositories may not deteriorate upon an increase in the applied temperature from $85^{\circ} \mathrm{C}$ to $150{ }^{\circ} \mathrm{C}$.

\section{Conclusions}

In this paper, the influence of the thermal and thermo-hydraulic gradients on the thermo-hydro-mechanical response of compacted bentonite specimens is presented. At the opposite end of compacted bentonite specimens two different temperature boundary conditions were considered, such as $85{ }^{\circ} \mathrm{C}$ and $25{ }^{\circ} \mathrm{C}$, and $150{ }^{\circ} \mathrm{C}$ and $25^{\circ} \mathrm{C}$. The test results obtained were the transient temperature and relative humidity at predetermined depths of the specimens and the axial stress. The water content, dry density, and degree of saturation along the depth of the bentonite specimens were determined after the termination of the tests. The investigation showed that,

- Due to an applied thermal gradient, a rise in the temperature within compacted bentonites depends upon the characteristics of the thermal insulation surrounding the compacted bentonites. The heat emission reduced and the relative humidity decreased when a thicker insulation was used. 
- Thermal gradients caused redistribution of water content, whereas thermo-hydraulic gradients caused both redistribution and an increase in the water content within compacted bentonites leading to development of axial stress of various magnitudes.

- Under the applied thermal and thermo-hydraulic gradients, the dry density increased near the heat source, whereas it decreased at the opposite end. A variation in the dry density is attributed due to the shrinkage of bentonite at and near the heat source. The drying of bentonite due to high temperature application was reduced in the presence of the hydration source. An increase in the water content and degree of saturation towards the opposite end of heat source indicated development of a low permeable zone at the interface between the restraint and unsaturated bentonite.

- Applied water injection pressure and an increase in temperature from 85 to $150{ }^{\circ} \mathrm{C}$ appeared to have very minimal effect on the evolution of axial stress.

Acknowledgments: This study has been funded by the Engineering and Physical Sciences Research Council (EPSRC) as part of the Systems Approach for Engineered (SAFE) Barriers project.

Author Contributions: The authors (Snehasis Tripathy, Hywel Rhys Thomas and Panagiotis Stratos) contributed equally in conceiving, designing and performing the experiments, analysing the experimental data, and writing the paper.

Conflicts of Interest: The authors declare no conflict of interest.

\section{References}

1. Pusch, R. Mineral-water interactions and their influence on the physical behavior of highly compacted $\mathrm{Na}$ bentonite. Can. Geotech. J. 1982, 19, 381-387. [CrossRef]

2. Gray, M.N.; Cheung, S.C.H.; Dixon, D.A. Swelling pressures compacted bentonite/sand mixtures. Mater. Res. Soc. Symp. Proc. 1985, 44, 523-530. [CrossRef]

3. Müller-Vonmoos, M. Bentonit und Radioaktive Abfälle. Neue Zürcher Zeitung, Forschung und Technik, 1 October 1986.

4. Pusch, R.; Yong, R.N. Microstructure of Smectite Clays and Engineering Performance; Taylor \& Francis: London, UK, 2006.

5. Martın, M.; Cuevas, J.; Leguey, S. Diffusion of soluble salts under a temperature gradient after the hydration of compacted bentonite. Appl. Clay Sci. 2000, 17, 55-70. [CrossRef]

6. Börgesson, L.; Chijimatsu, M.; Fujita, T.; Nguyen, T.S.; Rutqvist, J.; Jing, L. Thermo-hydro-mechanical characterisation of a bentonite-based buffer material by laboratory tests and numerical back analyses. Int. J. Rock Mech. Min. Sci. 2001, 38, 95-104. [CrossRef]

7. Cuevas, J.; Villar, M.V.; Martın, M.; Cobena, J.C.; Leguey, S. Thermo-hydraulic gradients on bentonite: distribution of soluble salts, microstructure and modification of the hydraulic and mechanical behaviour. Appl. Clay Sci. 2002, 22, 25-38. [CrossRef]

8. Pintado, X.; Ledesma, A.; Lloret, A. Backanalysis of thermohydraulic bentonite properties from laboratory tests. Eng. Geol. 2002, 64, 91-115. [CrossRef]

9. Singh, R.M. An Experimental and Numerical Investigation of Heat and Mass Movement in Unsaturated Clays. Ph.D. Thesis, Cardiff University, Cardiff, UK, August 2007.

10. Villar, M.V.; Lloret, A. Dismantling of the first section of the FEBEX in situ test: THM laboratory tests on the bentonite blocks retrieved. Phys. Chem. Earth 2007, 32, 716-729. [CrossRef]

11. Villar, M.V.; Sánchez, M.; Gens, A. Behaviour of a bentonite barrier in the laboratory: Experimental results up to 8 years and numerical simulation. Phys. Chem. Earth 2008, 33, 476-485. [CrossRef]

12. Samper, J.; Zheng, L.; Montenegro, L.; Fernández, A.M.; Rivas, P. Coupled thermo-hydro-chemical models of compacted bentonite after FEBEX in situ test. Appl. Geochem. 2008, 23, 1186-1201. [CrossRef]

13. Åkesson, M.; Jacinto, A.C.; Gatabin, C.; Sanchez, M.; Ledesma, A. Bentonite THM behaviour at high temperatures: Experimental and numerical analysis. Géotechnique 2009, 59, 307-318. [CrossRef]

14. Pusch, R.; Kasbohm, J.; Thao, H.T.M. Chemical stability of montmorillonite buffer clay under repository-like conditions-A synthesis of relevant experimental data. Appl. Clay Sci. 2010, 47, 113-119. [CrossRef] 
15. Gómez-Espina, R.; Villar, M. Geochemical and mineralogical changes in compacted MX-80 bentonite submitted to heat and water gradients. Appl. Clay Sci. 2010, 47, 400-408. [CrossRef]

16. Bag, R. Coupled Thermo-Hydro-Mechanical-Chemical Behaviour of MX80 Bentonite in Geotechnical Applications. Ph.D. Thesis, Cardiff University, Cardiff, UK, 2011.

17. Villar, M.V.; Martin, P.L.; Romero, F.J. Long-Term THM Tests Reports: THM Cells for the HE-E Test: Update of Results until February 2014; CIEMAT Technical Report CIEMAT/DMA/2G210/03/2014, Long-Term Performance of Engineered Barrier Systems PEBS; CIEMAT: Madrid, Spain, 7 March 2014.

18. Tripathy, S.; Thomas, H.R.; Bag, R. Geoenvironmental Application of Bentonites in Underground Disposal of Nuclear Waste: Characterization and Laboratory Tests. J. Hazard. Toxic Radioact. Waste 2017, 21, D4015002. [CrossRef]

19. Pusch, R.; Karnland, O. Physico/chemical stability of smectite clays. Eng. Geol. 1996, 41, 73-85. [CrossRef]

20. Wersin, P.; Johnson, L.H.; McKinley, L.G. Performance of the bentonite barrier at temperature beyond $100{ }^{\circ} \mathrm{C}$, A critical review. Phys. Chem. Earth 2007, 32, 780-788. [CrossRef]

21. Hicks, T.W.; White, M.J.; Hooker, P.J. Role of Bentonite in Determination of Thermal Limits on Geological Disposal Facility Design; Report 0883-1, Version 2; Falson Sciences Ltd.: Rutland, UK, September 2009.

22. Sellin, P.; Leupin, O.X. The use of clay as an engineered barrier in radioactive-waste management-A review. Clays Clay Miner. 2013, 61, 477-498. [CrossRef]

23. Horseman, S.T.; McEwan, T.J. Thermal constraints on disposal of heat-emitting waste in argillaceous rocks. Eng. Geol. 1996, 41, 5-16. [CrossRef]

24. Zheng, L.; Rutqvist, J.; Birkholzer, J.T.; Liu, H. On the impact of temperature up to $200{ }^{\circ} \mathrm{C}$ in clay repositories with bentonite engineer barrier systems: A study with coupled thermal, hydrological, chemical, and mechanical modeling. Eng. Geol. 2015, 197, 278-295. [CrossRef]

25. Carter, M.R. Soil Sampling and Methods of Analysis. Canadian Society of Soil Science; Lewis Publishing/CRC Press: Boca Raton, FL, USA, 1993.

26. ASTM. Standard Test Method for Shrinkage Factors of Soils by the Wax Method (D 4943-08). In 2010 Annual Book of ASTM Standards. Vol. 04.08. Soil and Rock (I); American Society for Testing and Materials: Philadelphia, PA, USA, 2010.

27. Lloret, A.; Villar, M.V.; Sanchez, M.; Gens, A.; Pintado, X.; Alonso, E.E. Mechanical behaviour of heavily compacted bentonite under high suction changes. Géotechnique 2003, 53, 27-40. [CrossRef]

28. Thomas, H.R.; Cleall, P.J.; Chandler, N.; Dixon, D.; Mitchell, H.P. Water infiltration into a large-scale in-situ experiment in an underground research laboratory. Géotechnique 2003, 53, 207-224. [CrossRef]

29. Farouki, O.T. Thermal Properties of Soils; CRREL Monograph 81-1; US Army Corps of Engineers, Cold Regions Research and Engineering Laboratory: Hanover, NH, USA, December 1981. 